Allegoria ad ornamentum architecturae: docere, delectare, movere.

\title{
Allegoria ad ornamentum architecturae: docere, delectare, movere.
}

DOI: $10.46814 / \operatorname{lajdv3n5-024}$

Recebimento dos originais: 01/05/2021

Aceitação para publicação: 31/06/2021

\section{Daniele Nunes Caetano de Sá}

Doutorado em Literatura Comparada

Escola de Arquitetura da Universidade Federal de Minas Gerais (EAUFMG): Rua Paraíba 697,4o andar, Savassi, Belo Horizonte - MG. Cep: 30130-141

E-mail: danielecaetano@terra.com.br

\section{RESUMO}

O texto interpreta a alegoria na arquitetura sacra colonial brasileira enquanto recurso retórico destinado à materialização da estrutura teológico-política do Antigo Regime, qual seja, a exaltação dos postulados cristãos e o reforço da hierarquia política luso-brasileira baseada fundamentalmente no conceito da "sociedade do corpo místico". Considerando que a estruturação social e comportamental seiscento-setecentista luso-brasileira é regrada por modelos e preceitos retóricos cumpre descortinar o processo de produção das alegorias bem como sua recepção naquele momento e na atualidade. A alegoria deve ser interpretada com base nas tratadística das artes e da arquitetura vigentes no período as quais apontam para a circularidade cultural dos princípios clássicos da retórica e da poética. Aponta, portanto, para a habilidade de interpretação dos distintos públicos naquele momento. Na atualidade a interpretação alegórica torna-se ainda mais hermética volvendo necessária a recuperação do patrimônio mnemônico das alegorias como elementos essenciais para entendimento da sociedade e da arquitetura religiosa no Brasil Colônia.

Palavras Chave: Alegoria, Arquitetura religiosa colonial, Práticas de representação, Retórica.

\section{RESUMEN}

El tex to interpreta la alegoría en la arquitectura sagrada colonial brasileña como un recurso retórico destinado a materializar la estructura teológico-política del Antiguo Régimen, es decir, la exaltación de los postulados cristianos y el refuerzo de la jerarquía política luso-brasileña basada en el concepto de "sociedad del cuerpo místico". Teniendo en cuenta que la estructuración social y de comportamiento luso-brasileña de los siglos XVI y XVIII se rige por modelos y preceptos retóricos, es necesario desvelar el proceso de producción de las alegorías así como su recepción en aquella época y en el presente. La alegoría debe interpretarse a partir de los tratados de artes y arquitectura vigentes en la época que señalan la circularidad cultural de los principios clásicos de la retórica y la poética. Apunta, por tanto, a la capacidad de interpretación de los diferentes públicos de la época. En la actualidad, la interpretación alegórica se vuelve aún más hermética, lo que hace necesario recuperar el patrimonio mnemónico de las alegorías como elementos esenciales para comprender la sociedad y la arquitectura religiosa en el Brasil colonial.

Palabras Clave: Alegoría, Arquitectura religiosa colonial, Prácticas de representación, Retórica. 


\section{O CONCEITO DE ALEGORIA}

Etimologicamente, alegoria deriva de allos - outro, e agoreúo - falar na ágora, utilizar linguagem pública. No latim, inversio apresenta um sentido diverso e até contrário, significando "o que está no lugar de uma outra coisa", ou "o que apresenta indiretamente uma coisa por meio de uma outra", ou ainda "o falar de uma coisa por meio de outra”. No mundo clássico é convencional o que é natural, ou seja, há um texto implícito que necessita ser decodificado a partir do desvelamento alegórico, pautado em regras discursivas pertinentes tanto ao autor, quanto ao fruidor.

Na retórica clássica, a alegoria é um ornatus ou ornamento discursivo, definida como metáfora ou tropo de pensamento baseada em uma relação de semelhança, ou seja, enquanto figura de linguagem, a alegoria parte da relação entre dois elementos figurativos para expressar um significado abstrato, assim como a metáfora. O que as distingue é que a metáfora se apóia na semelhança entre duas palavras diversas, enquanto na alegoria sintática o significante pode ser constantemente alterado. Postulando a convenção e a naturalidade do discurso ancorado nas categorias de brevidade, clareza e verossimilhança, a clareza determina a aceitação ou não do dispositivo alegórico e, em última instância, sua recepção, implicando a partilha comum da convenção entre obra e fruidor, visando à persuasão: ensinar (docere), agradar (delectare) e mover (movere).

Para Cesare Ripa, no livro Iconologia, datado de 1593, a alegoria da persuasão é representada por uma mulher vestindo um hábito traspassado por cordões dourados, representação da destreza e eloquiência com que se amarram os ouvintes. Segura com uma corda um animal de três cabeças: benevolência, docilidade e o cuidado necessários à eloquiência do falar. O cabelo refere-se ao Egito antigo e representa a palavra como o principal e mais necessário instrumento na arte de persuadir ${ }^{1}$. (Figura 1).

O emprego de metáforas distanciadas coíbe o verossímil, lacera o decoro e nulifica a alegoria. Enquanto técnica discursiva, a alegoria pode tanto clarificar uma passagem demasiadamente hermética, quanto ornamentar um discurso simplório. Enquanto recurso retórico, sua validade pressupõe o ato de recepção e interpretação pelo público.

O emprego de metáforas distanciadas coíbe o verossímil, lacera o decoro e nulifica a alegoria. Enquanto técnica discursiva, a alegoria pode tanto clarificar uma passagem demasiadamente hermética, quanto ornamentar um discurso simplório. Enquanto recurso retórico, sua validade pressupõe o ato de recepção e interpretação pelo público.

\footnotetext{
${ }^{1}$ RIPA, Cesare. Iconologia. Milano: Editori Associati S. p. A., 1992.
} 


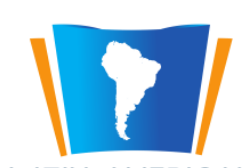

LATIN AMERICAN

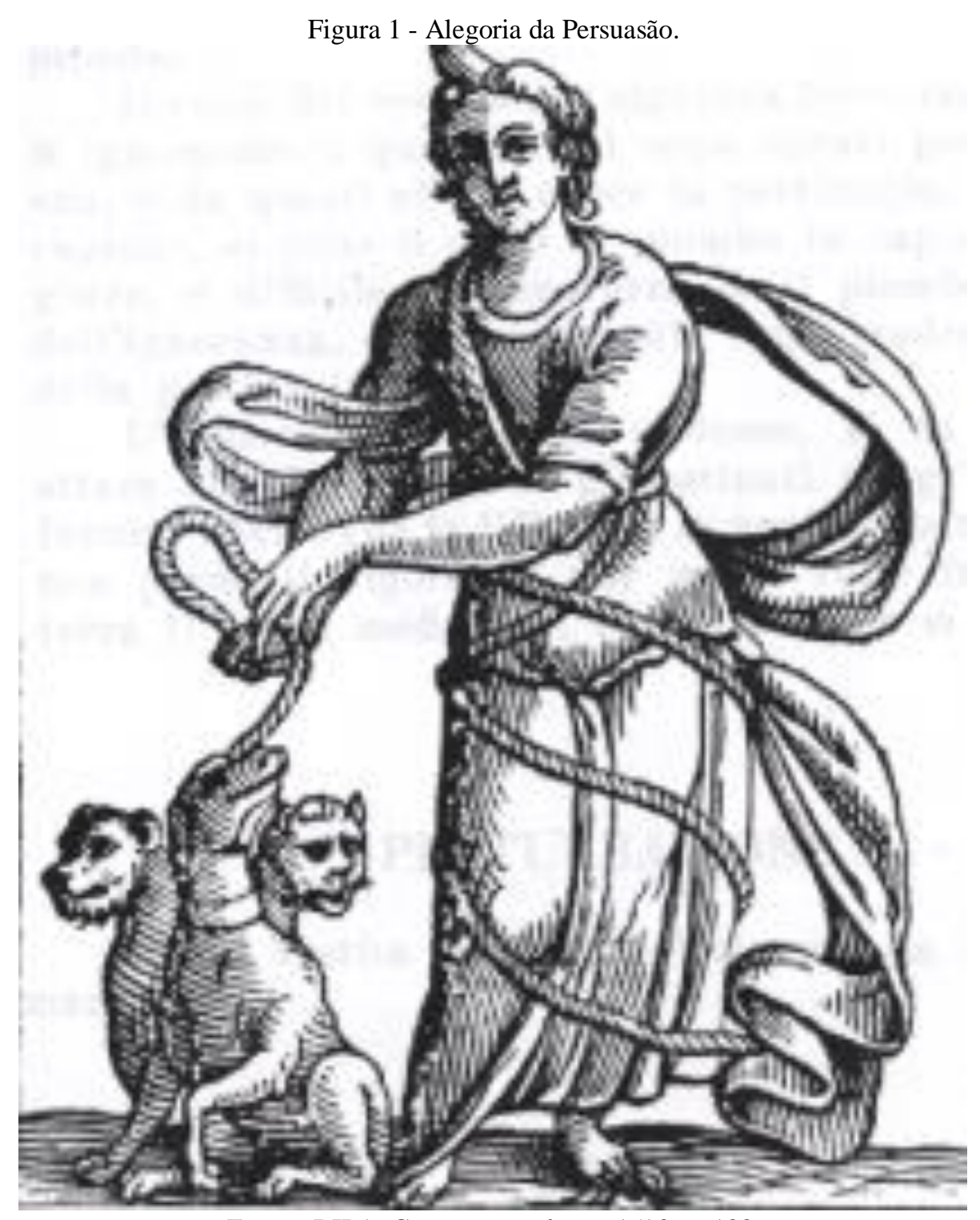

Fonte - RIPA, Cesare, Iconologia. 1593, p. 188.

A abordagem alegórica é intertextual e racional, demandando conhecimentos acerca dos conteúdos que determinam seu sentido, ou, “quem é novo não é capaz de distinguir o que é alegórico do que não é". ${ }^{2}$ O novo refere-se à capacidade intelectual do indivíduo em decifrar a alegoria. De outro modo, a alegoria, enquanto discurso racional e cifrado, demanda o entendimento de seus códigos ordenadores para a efetiva ressignificação do discurso implícito em torno do qual ela se estrutura.

A rigor, são duas as modalidades da alegoria: a construtiva ou retórica, operação discursiva ligada à retórica; e a interpretativa ou hermenêutica, prática interpretativa vinculada ao transcendente. ${ }^{3}$

\footnotetext{
2 PLATÃO. República, II: 378d.

${ }^{3}$ [...] frente a um texto que se supõe alegórico, o leitor tem dupla opção: analisar os procedimentos formais que produzem a significação figurada, lendo-a apenas como convenção lingüística que ornamenta um discurso próprio, ou analisar a significação figurada nela pesquisando seu sentido primeiro, tido como preexistente nas coisas e, assim, revelado na alegoria. In: HANSEN, João Adolfo. Alegoria. Construção e interpretação da metáfora. São Paulo: Atual, 1987, p. 2.
} 
A primeira, objeto de nosso interesse, refere-se à oposição entre sentido próprio e figurado, ou seja, este último é a metáfora, caracterizada como desvio do sentido literal, de modo que a alegoria retórica é mimética, funcionando por semelhança e um procedimento intencional da autoria. A segunda modalidade de alegoria, a hermenêutica ou interpretativa, também denominada "alegoria dos teólogos", é uma expressão retórico-poética da interpretação religiosa de textos sagrados, bíblicos, pressupondo o essencialismo, absolutamente estranho ao universo retórico greco-latino. Assim, na alegoria hermenêutica, o foco recai sobre a interpretação do Antigo Testamento como prefiguração do Novo, não se objetivando as palavras do texto, mas o "simbolismo lingüístico revelador de um simbolismo natural, das coisas, escrito desde sempre por Deus na Bíblia e mundo". ${ }^{4}$ Toda a significação é, portanto, ascensional, vinculada em última instância à graça divina, e muitos teólogos lançam mão da alegoria como estratégia para a exegese bíblica, dada a necessidade de mediação entre o texto e o fiel. $^{5}$

Há, na alegoría, retórica dois sentidos: um próprio, da ordem do inteligível (o primeiro dos termos da comparação) e outro figurado ou sensível, implícito no tropo e dependente da decifração pelo receptor, a qual envolve operações racionais, lógicas, mediadas pela metáfora, sendo, ao mesmo tempo, intelectual e afetiva. Pensada como ornamento, a alegoria, no Instituições oratórias de Quintiliano, é um tropo de pensamento, a transposição semântica de um signo presente para um ausente, mediado pelo critério da semelhança metafórica: ${ }^{6}$

Com o ornato, porém, e adorno do discurso, o mesmo orador se faz recomendar; e ao mesmo tempo em que nas mais coisas ele procura o juízo e a aprovação dos sábios, aqui procura também o louvor popular [...] porque os que estão ouvindo, quando sentem gosto, dão mais atenção ao que ouvem, e deste modo com mais facilidade se comovem. (QUINTILIANO, 1994, p. 41-42).

Cabe pois ao leitor estabelecer a transposição metafórica entre os termos ordenados segundo os lugares-comuns, sendo que tal ordenação demanda, por parte do poeta, a utilização decorosa dos tópoi para mediar a relação entre obra e receptor. Assim, em seu processo produtivo, a alegoria retórica é regrada a partir de lugares-comuns, princípios argumentativos de uma determinada interpretação do mundo cuja força reside no fato de abarcar as opiniões comuns, admitidas e aceitas. A evocação de um tópos induz a uma conclusão discursiva na medida em que o enunciado contém um entendimento compartilhado.

\footnotetext{
${ }^{4}$ HANSEN, João Adolfo. Alegoria. Construção e interpretação da metáfora, p. 4.

${ }^{5}$ A linguagem alegórica manteve-se sempre vinculada ao sagrado no que diz respeito à tradição católica, porém, perdeu toda sua capacidade interpretativa na tradição inaugurada por Lutero que abandonou o sensus allegoricus pelo sensus litteralis.

6 "A alegoria, que nós interpretamos inversão do sentido, é a que mostra uma coisa nas palavras, e outra no sentido, e às vezes também o contrário.” In: QUINTILIANO. Instituições oratórias. São Paulo: Cultura, 1994, III, VII, 1.
} 
A partir do século XV a alegoria é pensada como uma relação entre as partes e o todo, entre coisas próximas e distantes, criando objetos visíveis a partir de analogias ao invisível, como mistérios a serem interpretados. A descoberta da Poética aristotélica, em 1499, reconduz a alegoria, nos séculos XVI e XVII, ao conceito de tropo convencional e, enquanto metáfora continuada, ela passa a ser entendida como uma invenção, uma disposição retórica que dá forma a um pensamento, a um conceito, materializado na imagem. Baltasar Gracián, em sua Agudeza y arte de ingenio, e Emanuele Tesauro, no Cannochiale aristotélico, evidenciam a supremacia da tota allegoria ou da mala effectatio como estratégias discursivas, tendo em vista o caráter engenhoso e agudo envolvido em sua produção e recepção.

O empenho não consiste na elaboração de um novo tema, mas na disposição engenhosa das tópicas, por intermédio das quais o tema velho se converte em novo, mantendo a tradição. O engenho do poeta deve buscar o artificioso da alegoria, baseando-se no verossímil que move a agudeza do próprio fruidor, co-autor da obra, como demonstra Emanuele Tesauro no livro Argúcias Humanas:

O engenho natural é uma maravilhosa força do intelecto, que compreende dois talentos naturais: perspicuidade e versatilidade. A perspicuidade penetra nas mais longínquas e diminutas circunstâncias de cada objeto, como substância, matéria, forma, acidente, propriedades, causas, efeitos, fins, simpatias, o semelhante, o contrário, o igual, o superior, o inferior, as insígnias, os nomes próprios e os equívocos: coisas que jazem ocultas e enoveladas em qualquer assunto, como diremos no momento oportuno. A versatilidade compara rapidamente todas estas circunstâncias entre si ou com o assunto: junta-as ou divide-as, aumenta-as ou diminui-as, deduz uma da outra, indica uma pela outra e, com maravilhosa destreza, põem uma no lugar da outra, como os jogadores (TESAURO, 1997, p. 4). ${ }^{7}$ (Figura 2).

$\mathrm{Na}$ alegoria do engenho de Ripa, o jovem alado e desnudo porta um capacete encimado por uma águia, representando a visão aguda; sustenta uma flecha na mão direita e, na esquerda, um arco, representação da agudeza, talento e força do poder intelectual. O engenho é, assim, entendido como uma potência intelectual do espírito que jamais envelhece.

\footnotetext{
7 TESAURO. Argúcias humanas, p. 4.
} 




Fonte - RIPA, Cesare, Iconologia. 1593, p. 188.

Desse modo, a alegoria torna-se intelectualista, objetivando a persuasão e o enquadramento do público à estrutura teológico-política vigente no Antigo Regime. Logo, toda interpretação alegórica remonta à exaltação do Império político ou da Igreja Católica, instituições ordenadoras da estruturação social do momento.

Em sentido último, ela remonta à morte, ao luto e à ausência de vida, como representado na alegoria presente na Basílica de São Pedro em Roma. O esqueleto, a caveira, bem como a ampulheta retratam a perenidade temporal, concomitantemente a posição ascensional dos braços e da ampulheta ratifica a certeza no porvir, restando ao sujeito viver bem para bem morrer. Nos dizeres de Walter 




Benjamin, o "cadáver é o supremo adereço cênico, emblemático, do drama barroco do século XVII. Sem ele as apoteoses seriam praticamente inconcebíveis". ${ }^{8}$ (Figura 3).

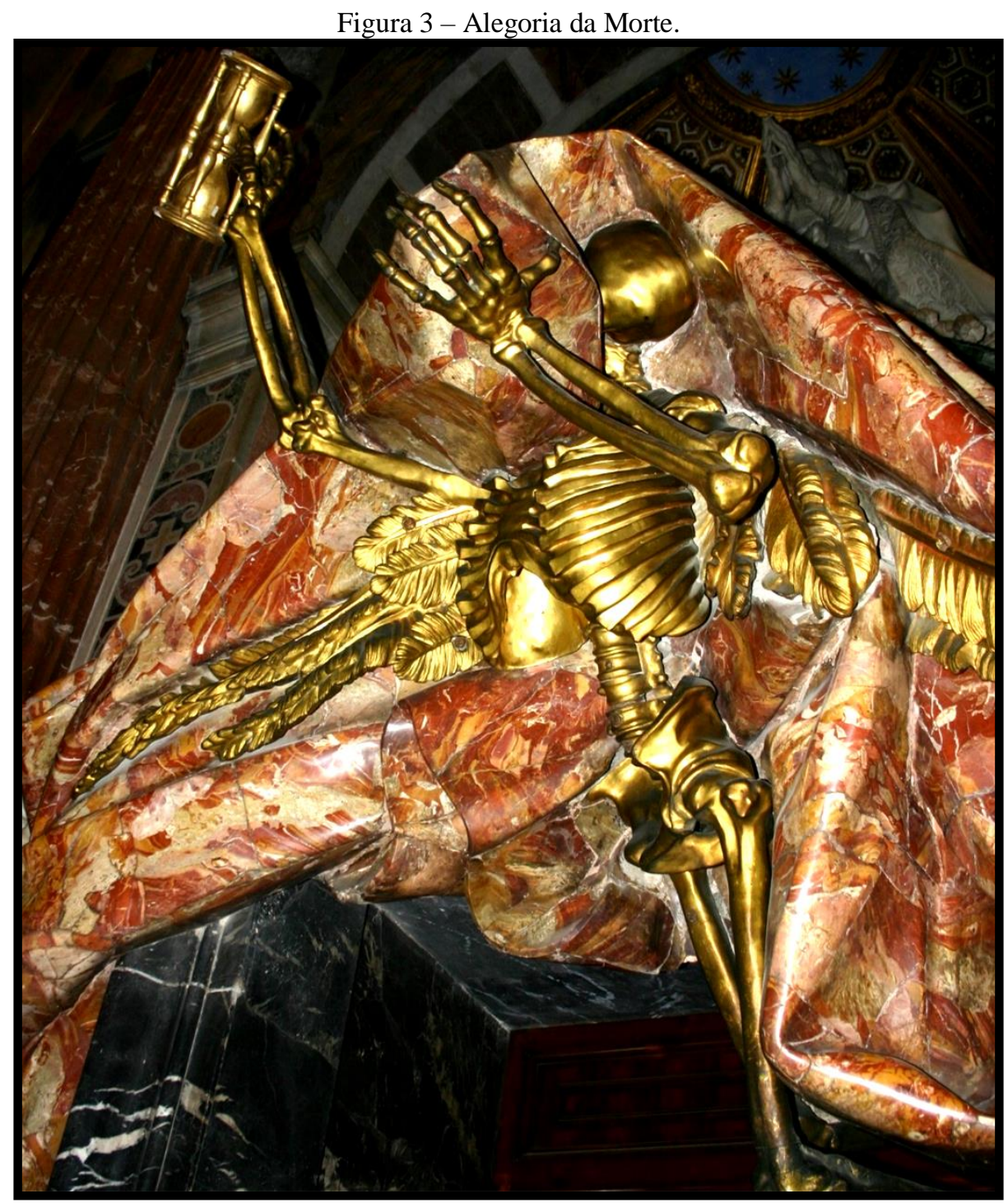

Fonte - arquivo pessoal

Segundo Emile Mâle no El arte religioso del siglo XII al siglo XVIII, o século XVII consegue dar uma versão ainda mais impressionante da morte se comparado com a Idade Média, pois a arte, depois do Concílio de Trento, "pôs o cristão frente à morte para ensinar-lhe a não temê-la e ao mesmo tempo lhe abriu o céu." "A alegorização da morte remete sempre à idéia de que subsiste a aspiração pelo divino em meio à organização racional do mundo, ou seja, a partir da alegoria da morte, o homem

\footnotetext{
${ }^{8}$ BENJAMIN, Walter. Origem do drama barroco alemão. Tradução: Sérgio Paulo Rouanet. São Paulo: Brasiliense, 1984, p. 242.

${ }^{9}$ MÂLE, Emile. El arte religioso del siglo XII ao siglo XVIII. Cidade do México: Fondo de Cultura Económica, [s.d], p.192.
} 
se depara com a efemeridade da vida, é persuadido pela busca da virtude e enquadra-se à teologiapolítica vigente, alicerçada nos princípios virtuosos como meio de ascensão ao divino. O tema da morte promove uma catarse individual e posteriormente coletiva em que o objetivo é a boa morte, ou a sabedoria de morrer bem ou, desde que enquadrado ao sistema teológico-político, o sujeito pode, através da morte, certificar-se da visão beatífica de Deus, como representa a alegoría da norte da Basílica de São Pedro em Roma.

Uma das mais significativas obras hispano-americanas relacionadas com o tema da morte se encontra no Museu Nacional do Virreinato, no México. De autor desconhecido, elaboradas antes de 1775, seis emblemas miniaturizados retratam o tema da morte. A estampa selecionada evidencia um sepulcro presidido por uma caveira e duas velas. Abaixo, aparece um esqueleto entre dois emblemas: o da esquerda, com um ramo de flores, tem como tema, a União entre as variedades e o da direita, representando um coração que resiste aos golpes de um martelo e às flechas de um arco, tem, como tema, Nem o golpe, nem as iras. Os epigramas relatam a insignificância do homem, a certeza da morte e da clemência divina. (Figura 4). 


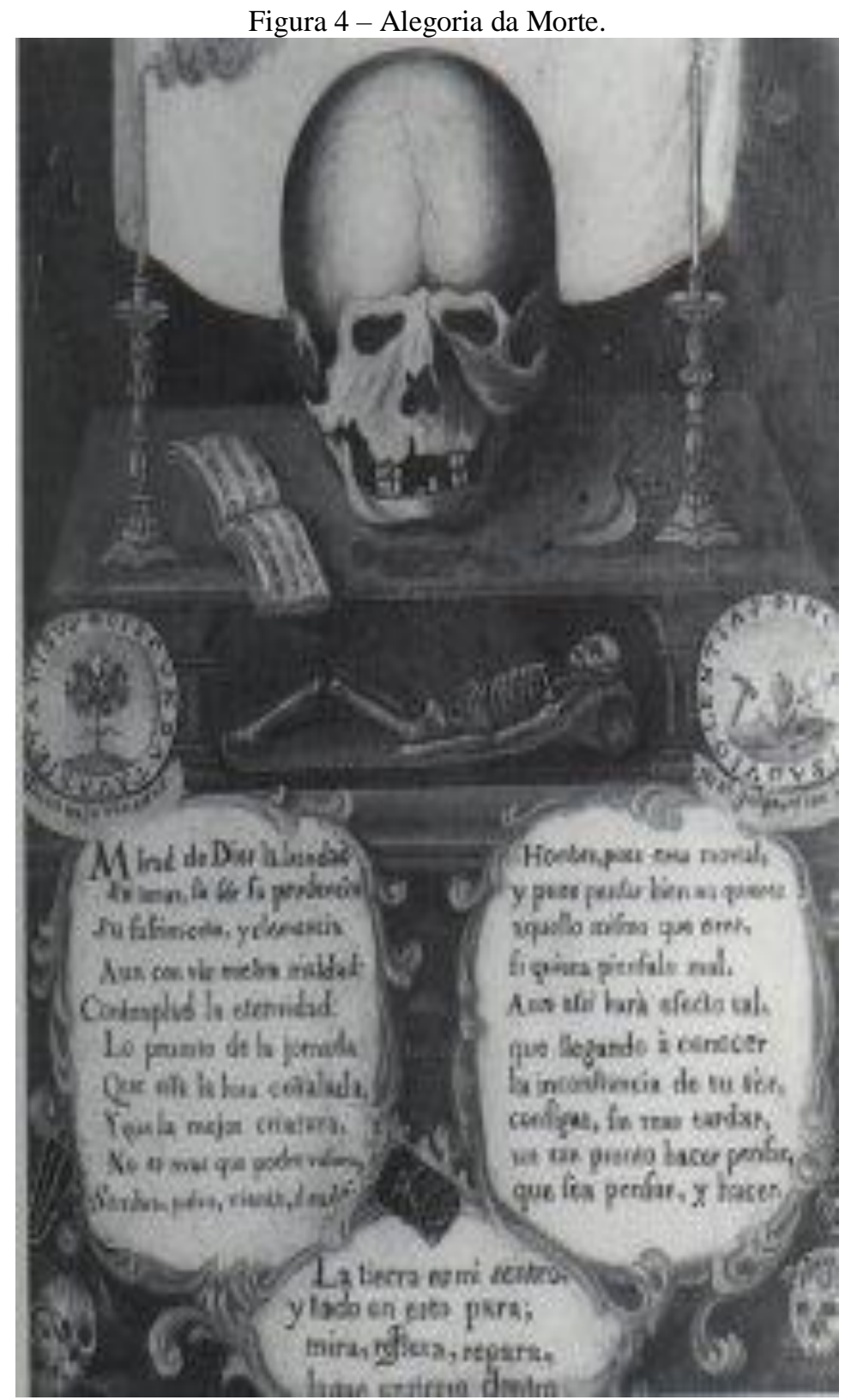

Fonte - Museu Nacional do Virreinato.

\section{ALEGORIA SEISCENTO-SETECENTISTA na arquitetura sacra LUSO-BRASILEIRA}

O foco de análise concentra-se no pressuposto de que a dominação da colônia brasileira foi possibilitada pela constituição de uma identidade comum entre portugueses e colonos e que as práticas de representação artístico-culturais podem ser interpretadas como um conjunto de técnicas codificadas que evidenciam a hierarquia fundamentada na teologia política do Estado do corpo místico.

No Antigo Regime, o rei tem em si mesmo duas pessoas e dois corpos indivisíveis, estando cada um inteiramente contido no outro: o corpo natural, representado pela pessoa física e mortal - 


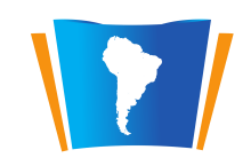

LATIN AMERICAN

persona personalis - e o corpo político, representado pela pessoa imortal e sagrada - persona idealis ou persona mystica ${ }^{10}$ - representada pelo povo que se aliena a partir do pacto de sujeição ${ }^{11}$. (Figura 5)



Fonte - RIPA, Cesare, Iconologia. 1593, p. 376.

A doutrina do pactum subjectionis/pacto de sujeição do corpo místico do estado é elaborada por Francisco Suárez (1548-1617) defendendo a hipótese de que a sociedade, como um todo, numa espécie de quase alienação, transfere o poder ao rei em troca da administração do bem comum e condução virtuosa dos súditos.

Analogicamente, compara-se os dois corpos do rei com a dupla pessoa de Cristo, ao mesmo tempo homem e Deus enquanto o rei legitima sua autoridade com base no conceito de razão de estado, doutrina política estabelecida em uma sociedade hierarquizada e entendida como metáfora organicista, em que a integração harmônica dos membros, apesar de plurais e diversos, garante a unidade do corpo.

\footnotetext{
${ }^{10}$ KANTOROWICZ, Ernest H. Os dois corpos do rei - um estudo sobre teologia política medieval. São Paulo: Companhia das Letras, 1998.

${ }^{11}$ SUAREZ, Francisco. Defensio Fidei III, principatus politicus o la soberania popular. Madrid: Consejo superior de investigaciones cientificas, 1965.
} 
Analogicamente, como o corpo se submete à cabeça, o reino se submete ao rei e o mundo se submete a Deus. Estamos diante do conceito de monarquia mística, em que a Igreja é a extensão da coroa e a monarquia se afirma como sagrada.

Analisado como arte da decifração, o universo simbólico desse tempo lança mão de diversas categorias que vão desde a cosmologia até os reinos terrestres, passando pelas alegorias morais e comportamentais humanas, até as institucionais referentes ao Estado ou à Igreja. Os recursos alegóricos reforçam o caráter propagandístico da monarquia católica, já que há a consciência da função decisiva das imagens, 'idiotarum libri' - livros dos ignorantes -, numa propaganda voltada as massas compostas predominantemente de iletrados ${ }^{12}$, submetendo-as à moldura da ordem social vigente ${ }^{13}$. As representações se apropriam de convenções alegóricas culturalmente regradas e codificadas ${ }^{14}$, ou seja, da repetição contínua dos mesmos significantes para os mesmos significados e, concomitantemente, tornam-se herméticas, distanciando a figura representada de seu sentido imediato, necesitando que a agudeza possibilite a aproximação e fusão dos conceitos e conseqüente entendimento da representação ${ }^{15}$. (Figura 6).

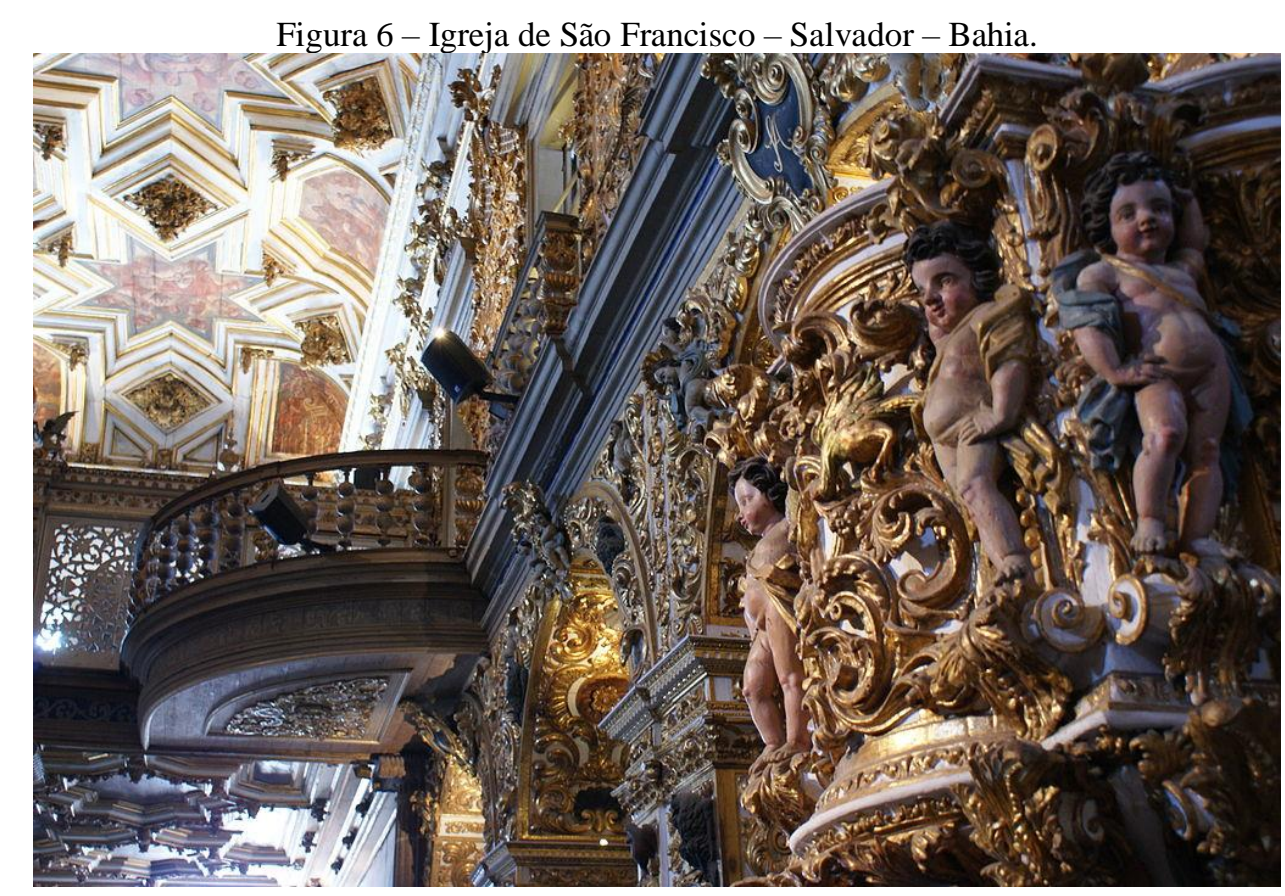

Fonte - Arquivo pessoal.

\footnotetext{
${ }^{12}$ GINZBURG, Carlo. Mitos, emblemas, sinais. São Paulo: Companhia das Letras, 1991, p. 121.

${ }^{13}$ MARAVALL, José Antônio. A cultura do barroco - análise de uma estrutura histórica. Barcelona: Arial, 1990, p. 89.

14 “Cada conceito é tratado segundo os cânones pré-estabelecidos, retoricamente fixos, do belo; [...] não está por inventar, pertence, pelo contrário, a um universo já formado, com leis pré-estabelecidas”. In: SARDUY, Severo. Barroco. Lisboa: Veja, 1989, p. 121.

${ }^{15}$ Uma das mais significativas convenções alegóricas do período é o entendimento do Velho Testamento como prefiguração do Novo. Assim o rei Davi é visto como um prenúncio de Jesus Cristo que, representado pela figura do cordeiro, faz alusão ao sacrifício de Isaac que, por sua vez, funciona como alegoria do sacrifício do próprio Cristo.
} 
Dentro do enquadramento das massas à monarquia católica portuguesa, as alegorias, linguagem que se vê e se lê através da significação simbólica; sensibilizam, primeiramente, os olhos e, posteriormente, comunicam ao intelecto a mensagem cifrada ou informação textual, funcionando como recurso narrativo e dirigismo pedagógico: a busca pela harmonia e unidade previstas pelo Estado e pela Igreja Católica. O convencionalismo da linguagem alegórica aponta, portanto, para o caráter conservador e autoritário do processo de dominação da Metrópole, chamando atenção o fato de que tais convenções ibero-americanas tornaram-se, atualmente, muitas vezes, ininteligíveis.

É preciso considerar que tais práticas de representação são, todas elas, de base retórica, ou seja, ordenadas segundo uma racionalidade que aplica afetos codificados e imitados de modelos ou esquemas coletivos. ${ }^{16}$ Com o objetivo de controle dos vícios, exaltação das e condução ao bem comum, o Estado português persuade, mediado pela teatralização dos princípios teológico-políticos, lançando mão das práticas de representações visuais entendidas como proposições dogmáticas do poder monárquico e religioso e destinadas a modelar, normativamente, a sociedade. Por isso, tanto no plano físico quanto moral, os homens são governados e controlados por leis que não contrariam os parâmetros cristãos e monárquicos. A universalidade serve de fundo para o culto da razão ${ }^{17}$ e o processo mimético é, portanto, racionalizado e dirigido como o instrumento de conciliação da verdade postulada pela Igreja Católica e pela política absolutista.

A Poética e a Retórica aristótelicas são os principais referenciais teóricos normativos da produção artística. A partir da Poética, a mímesis é condicionada pelo princípio ut pictura poesis. Sendo a poesia uma "imitação das ações humanas", cabe a ela evidenciar os virtudes e repudiar os vícios. A Retórica, fonte fundamental da arte de persuasão do discurso político, destina-se à produção artística a partir do século XVI como gênero demonstrativo do pensamento político ou religioso e não relacionada somente aos textos de ficção, o que nos permite falar de uma "retórica da arquitetura e das outras artes plásticas". ${ }^{18}$ De outro modo, os tratadistas e preceptistas do século XVII e XVIII ressaltam a necessidade de afirmar o universal e a inalterabilidade do homem e da natureza.

As alegorias seiscento-setecentistas luso-brasileiras são formas não-psicológicas de representação visual elaboradas a partir de tópicas retóricas definidas por tratadistas e preceptistas e funcionam como instrumento de persuasão e reafirmação social, pois "toda a arte barroca [...] vem a ser uma drama estamental: a gesticulante submissão do indivíduo à moldura da ordem social". ${ }^{19}$ Isso equivale a dizer que, quanto maior a agudeza e engenhosidade, ou seja, quanto mais herméticos os

\footnotetext{
${ }^{16}$ HANSEN, João Adolfo. Notas sobre o barroco. In: Revista do IFAC, p.11-12.

${ }^{17}$ LIMA, Luiz Costa. O controle do imaginário - Razão e imaginação nos tempos modernos. Rio de Janeiro: Forense universitária, 1989, p. 41.

${ }^{18}$ SEBASTIAN, Santiago. El baroco iberoamericano - mensaje iconográfico. Madrid: Encuentro, 1990, p.23.

${ }^{19}$ MARAVALL, José Antônio. A cultura do Barroco -análise de uma estrutura histórica. Barcelona: Arial, 1990, p. 89.
} 
emblemas e alegorias, maior sua valorização, porque o entendimento fica restrito ao agudo. Ao contrário, o néscio ou vulgar não possui a erudição necessária para a interpretação das representações ${ }^{20}$. Nesse caso, é a memória coletiva de lugares-comuns, instituída principalmente através das pregações religiosas e ênfase na visibilidade imagética, que torna possível o entendimento por parte dos iletrados. A possibilita, pedagogicamente, ver em formas sensíveis aos olhos aquilo que, nas letras, são formas inteligíveis, ocultas. A imagem pode ser vista e assimilada por aqueles que não entendem o mote ou o epigrama, enquanto o entendimiento visual e textual significa a compreensão da imagem em sua plenitude, ou seja, horacianamente, a imagem como algo que se lê e a escrita como algo que se vê ${ }^{21}$. Há, portanto, um componente intrinsecamente hierárquico na apropriação das imagens, o que equivale a dizer que os emblemas e alegorias reafirmam a hierarquia da Colônia na medida em que repõem a ordem social quando adequados aos usos decorosos e articulam, metafísica e retoricamente, como ornato dialético, os conceitos da teologia política portuguesa.

Nos tratados alegóricos, grande parte das imagens figuram os deuses e heróis do mundo clássico, exigindo erudição e conhecimento do material literário para a análise. É a memória ${ }^{22}$, uma das cinco partes da retórica, que conserva e ordena os textos com as figurações, arquivando as informações necessárias para o entendimento dos emblema e alegorias. Á medida que as imagens passam a ser portadoras de valores convencionalmente designados, o destinatário pode lançar mão dos recursos mnemotécnicos dos tratados para elaborar sua própria memória artificiosa, ou seja, para desvendar o discurso contido no corpo de um emblema ou de uma alegoria. Um dos quadros mais difundidos da memória coletiva na sociedade luso-brasileira é o modelo das intenções disciplinadoras. Os comportamentos depravados, as relações adulterinas, práticas sexuais incestuosas e homossexuais e toda espécie de vícios são vistos como resultados de desvios comportamentais a serem severamente punidos. Além disso, a memória coletiva é reforçada pelos modelos do passado, fossem eles as autoridades ou personagens da história. Impregnam os sermões, o teatro e a iconografia a ponto de fornecer um dos quadros mais difundidos da memória coletiva. ${ }^{23}$

\footnotetext{
${ }^{20}$ A compreensão do conceito agudo vincula-se à erudição ou conhecimento dos autores clássicos, tornando possível a decifração das mensagens herméticas com base em conceitos retóricos. São, normalmente, homens de corte e distinguiamse pela agudeza. O néscio ou vulgar é o povo inculto. Cf. CASTIGLIONE, Baltassare. O Cortesão. São Paulo: Martins Fontes, 1997.

${ }^{21}$ Horácio estabeleceu três termos para a análise de uma obra: distância, luminosidade e número de vezes a ser vista e evidenciou, novamente, a supremacia da visão sobre a audição.

${ }^{22}$ A memória mereceu especial atenção do mestre romano desconhecido autor do tratado Ad Herennium, escrito no século I a.C. Genericamente, os tratados posteriores ao Ad Herennium sempre fizeram referência a ele.

${ }^{23}$ CURTO, Diogo Ramada. O discurso político em Portugal (1600-1650). Lisboa: Centro de Estudos e Cultura

Portuguesa, 1988, p.22.
} 
"O conhecimento do sucesso que as historias referem, ajuda muito a regular o presente, e a prever o futuro, effeito principal da prudencia, a qual como naceo da observação de casos particulares, creçe com raízes mais solidas no sujeito que tiver mais larga, e copiosa experiencia delles, com a lição da historia". (MENESES, 1650, P. 26) ${ }^{24}$.

O orador parte, então, das imagens fixadas em sua memória às palavras com que atualiza seu discurso. Por sua vez, o destinatário de um texto icônico-verbal parte das imagens contempladas para chegar à interiorização dos tópicos discursivos ${ }^{25}$. Assim, a alegoria costuma ser entendida como a representação de uma abstração e, nesse sentido, não se vincula apenas à linguagem verbal, mas também à pintura e escultura, tratando-se, pois, de uma concepção inventiva, no sentido de aguda e engenhosa, que tem como base as convenções sociais da discrição cortesã.

“[...] a partir de fins do século XVI, os jesuítas começaram a lançar mão dos livros de emblemas como veículo pedagógico e propaganda da fé, substituindo os motes dos emblemas por apólogos e moralizando as imagens. Com o objetivo de substituir o herói pagão pelo cristão, a fábula mitológica pela parábola evangélica, a linguagem se adapta à Ratio studiorum, tornando-se clara, clássica". (HANSEN, 1989, p.446) 26 (Figura 7).

\footnotetext{
${ }^{24}$ MENESES, Sebastião Cesar de. Summa politica offerecida ao Principe D. Theodosio de Portugal. Amsterdam: Simão Dias Soeiro Lusitano, 1650, p.26.

${ }^{25}$ BUXÓ, José Pascual. El resplandor intelectual de las imágenes: jeroglífica y emblemática. In: Juegos de ingenio y agudeza: la pintura emblemática de la nueva Espanã. Barcelona: Museo Nacional de Arte, 1994, p. 51.

${ }^{26}$ DOGLIO, Maria Luisa. "Introduzione" in Tesauro, Emanuele. Idea delle perfette imprese. Firenze, Leo S. Olschki, 1975, p.11. In: HANSEN, João Adolfo. A sátira e o engenho: Gregório de Matos e a Bahia do século XVIII. São Paulo: Companhia das Letras, 1989, p.446, nota 148.
} 




LATIN AMERICAN

Figura 7 - Matriz de Nossa Senhora do Pilar - Ouro Preto - Minas Gerais.

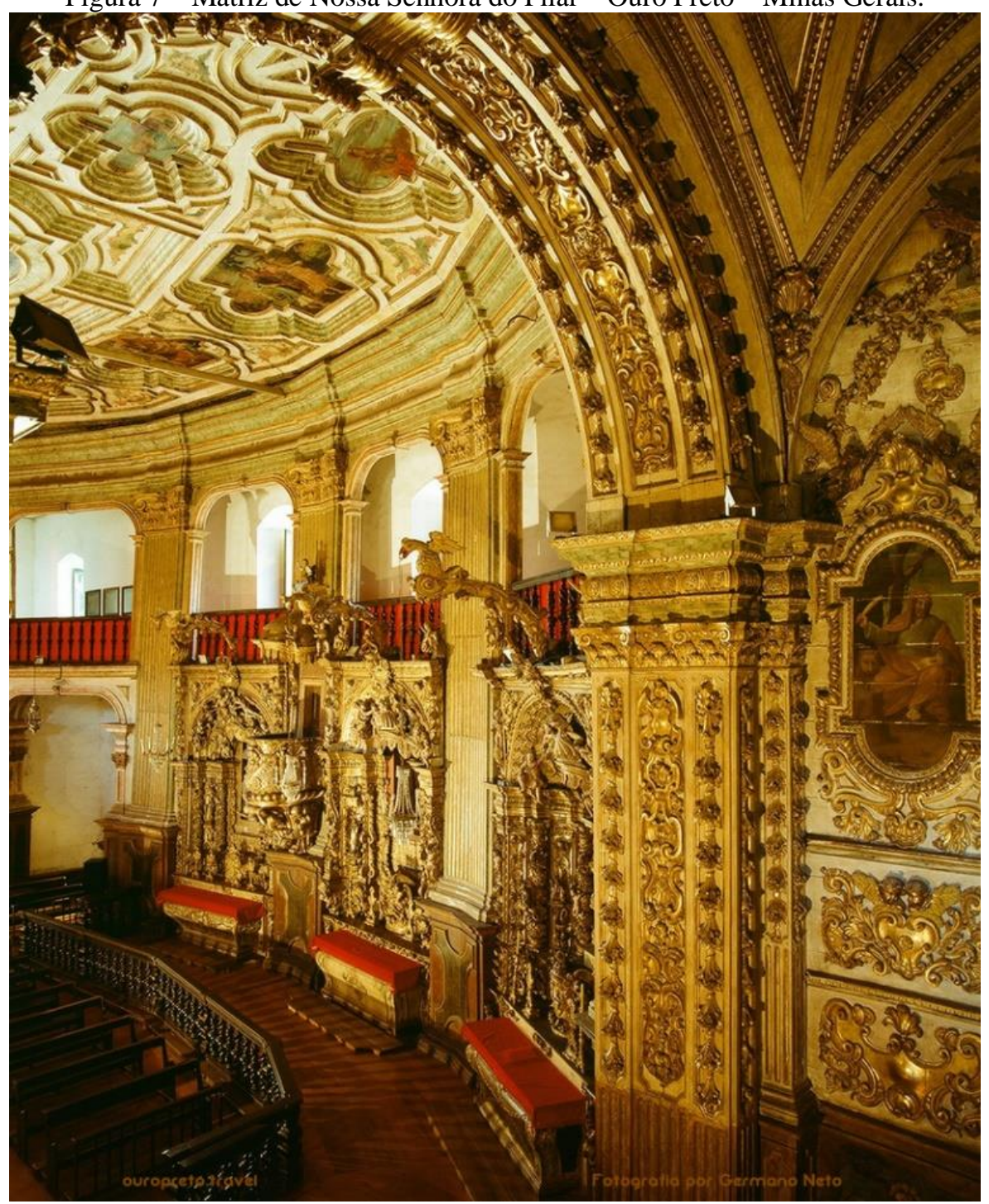

Fonte - Arquivo pessoal.

No final do século XV, a alegoria passa a ser entendida como um misto retórico-hermenêutico e interpretada, também, com base nos registros da Antiguidade oriental e greco-romana, unificando assim os mistérios pagãos às crenças do cristianismo. A alegoria seiscento-setecentista, proposta como técnica teatralizada de metáforas ${ }^{27}$ distantes, funde os dois métodos interpretativos: a retórica e a exegese bíblica.

\footnotetext{
"A junção do dispositivo retórico, que prevê o sentido próprio e o figurado, com o essencialismo cristão, que postula a glosa perene da letra, permite a autonomização dos grafismos como procedimento retórico-poético, comum na Idade Média, no Renascimento e no século XVII barroco". (HANSEN, 1987, 27) 28.
}

\footnotetext{
27 "Substituição de um termo por outro, fundamentada numa relação de semelhança, que permite expressar uma gama de significações mais ampla e densa do que o termo dito 'próprio' seria capaz de fazer". In: KOTHE, Flávio R. A alegoria. São Paulo: Ática, 1986, p.91.

${ }^{28}$ HANSEN, João Adolfo. Alegoria - Construção e interpretação da metáfora. 2. ed. São Paulo: Atual, 1987, p. 27.
} 
Parece-nos impossível analisar as alegorias e dissociá-las da própria arquitetura que as abriga, isso porque o ornato não é um simples acessório. O que se observa na arte dos séculos XVI e XVII é que o ornamento se torna estruturante e a íntima fusão de função e ornato é justamente o que define o ornato dialético ou a agudeza. Precipitado ao primeiro plano da percepção, o ornamento exige uma leitura retórica ao mesmo tempo em que há a propensão da estrutura em resolver-se como ornamento. "Enquanto o ornato renascentista é aplicado, acessório, o ornato setecentista é estrutural. Há um deslizamento constante do ornamento para a estrutura e vice-versa". ${ }^{29}$ No ornamento, a estrutura e os adornos se integram num conjunto de caráter dialético e pedagógico, pois, "tudo o que é adorno, e adorna, está determinado pela sua relação com o que ele adorna, com aquilo em que ele é, com aquilo que é seu portador" ${ }^{\prime 3}$.

\section{DECLÍNIO E ASCENSÃO DA ALEGORIA: DO ROMANTISMO A ATUALIDADE}

Contrariamente a artificiosidade seiscento-seiscentista, a alegoria passa a ser entendida como sinônimo de ornamentação discursiva principalmente a partir da Escola de Port-Royal e seu caráter de mero adorno é mantido até o Romantismo, quando se transforma de puro ornamento, em figura oposta ao símbolo. ${ }^{31}$ Com efeito as tradições greco-latinas, medievais e renascentistas, não distinguem a alegoria do símbolo, operada apenas a partir do Romantismo, que postula a supremacia do símbolo considerando a doutrina libertadora do gênio em relação as amarras dogmáticas mítico-religiosas. A significação imediata do símbolo expressa o geral, o universal no particular; enquanto a alegoria, permitindo a inclusão de novos significados, é temporalmente sucessiva. Da perspectiva romântica, a alegoria é considerada um rebuscamento discursivo gerador de uma distinção entre o sentido figurado e o próprio, enquanto o símbolo é a reabilitação do signo interpretado a partir de uma convenção ou hábito.

Na tentativa de evitar a dispersão das manifestações, o símbolo, e sua imediaticidade entre o universal e o particular, é o elemento centralizador das dispersões, decorrendo disso uma certa estaticidade, a princípio contrária ao dinamismo e individualidade propostos pelo Romantismo. Ao se voltar para o universal a partir do símbolo, o caráter múltiplo da obra termina enclausurado por sua linguagem e insuficiente para explicar uma realidade cada vez mais mutável. É por isso que, ao invés

\footnotetext{
${ }^{29}$ BRUZZI, Hygina Moreira. O ornamento estruturante: Reflexões sobre a primeira arquitetura barroca de Minas Gerais. Belo Horizonte: ACR - EAUFMG, 1999, p. 14. (Ensaio).

${ }^{30}$ GADAMER, Hans-Georg. Verdade e método. 3. ed. Petrópolis: Vozes, 1999, p. 255.

${ }^{31}$ Em relação ao símbolo, a alegoria difere devido à necessária relação contextual para seu desvelamento, ao seu caráter evidente de convenção retórica e à possibilidade de renovação constante de seu significado, permitindo a ampliação do espectro de significados contidos no símbolo.
} 
do imediatismo do símbolo, Walter Benjamin defende a obliqüidade alegórica, a qual permite interpretações múltiplas e abertas, num processo de ressignificação constante. Na interpretação Benjaminiana a alegoria expressa um mundo saturado de objetos, decorrência da perda de estatutos e da degradação ontológica da arte, a partir de sua negação do sagrado e da consciente materialidade advinda da reprodutibilidade técnica. ${ }^{32}$

Na reabilitação benjaminiana da alegoria, inteiramente condicionada pelo mundo melancólico, entendido como esvaziamento e ausência de significações, a alegoria redime a transitoriedade das coisas. No processo de alegorização, a ruína é deslocada de seu contexto e relançada em outros, tantos quanto possíveis, recebendo novas significações. O ponto de contato estabelecido por Benjamin entre a alegoria e a melancolia é o luto, a ruína ressemantizada, haja vista que, segundo ele, a experiência vivida, marcadamente dispersa através de uma "história de ruínas", impede a memória de consolidar as referências culturais passadas, dado o número cada vez mais exacerbado de informações distorcidas e fragmentárias que compõe a realidade. Há, portanto, um afastamento entre o sujeito e essa realidade, denominada de "nova barbárie", e, nessa perspectiva, a alegoria é reabilitada como possibilidade de redenção de cada fragmento de história e significação do real, ambicionando-se a verdade.

Ora, se, do ponto de vista da retórica, a alegoria é operacionalizada a partir do emprego decoroso dos tópoi, ou lugares-comuns do discurso, partilhados por autor e receptor, resta indagar quais os lugares comuns do discurso contemporáneo. A alegoria retórica contemporânea está, pois, associada à inconsistência da relação entre obra e fruidor, uma vez que a obra fala por si só. A validade do discurso alegórico demanda o estabelecimento de poéticas que reforçassem os tópoi contemporâneos para além da discursividade auto-referente, recuperando a dóxa, pois, sem a participação efetiva do receptor, incluindo sua capacidade de desvelamento do conteúdo alegórico da imagem, a obra aumenta sua distância em relação ao fruidor. A fragmentação discursiva, advinda do declínio da retórica, e a conseqüente auto-referencialidade da obra configuram ressignificações hiperbólicas, diminuindo o horizonte de expectativas e levando à perda do sentido. Cumpre o estabelecimento de poéticas que abarquem, conjuntamente, a autoria e o público, a partir da recuperação das categorías retóricas da inventio, dispositio e elocutio fundamentadas no saber e na experiência do "mundo da vida".

Com efeito, na atualidade a alegoria configura-se como tota allegoria, cujo significado se mantém hermético e cujo discurso é auto-referente, e, sob este aspecto, ela reforça a dispersão discursiva, dificultando a recepção. Sendo impossível abarcar a totalidade do mundo, fissurado em suas múltiplas fragmentações, as ressignificações da alegoria estimulam a falsa aparência de uma totalidade

\footnotetext{
${ }^{32}$ Os sentimentos de ruína e melancolia, reabilitariam a alegoria benjaminiana entendida a partir do pressuposto de que "os elementos aparentemente difusos e heterogêneos vão acabar se unindo, nos conceitos adequados, como partes integrantes de uma síntese".
} 
verdadeira. Seu poder de síntese, de fundir conceitos distantes e garantir novas significações é ceifado a partir do momento em que a auto-referencialidade discursiva passa a imperar nas poéticas da modernidade. Consistindo a alegoria em uma operação retórica racionalizada, efetuada pelo fruidor que estabelece o presente a partir de analogias com o ausente, o distanciamento entre sujeito e objeto denuncia a sua invalidade. Tendo em vista que pensamos por imagens e estas nos chegam cada vez mais fragmentadas e efêmeras, tornando-se descartáveis, os conceitos esvaecem-se na pluralidade e a alegoria não pode ser mais do que a utopia de uma totalidade verdadeira, sendo, no máximo, a denúncia da falsidade implícita da aparência do real. A alegoria é repertório puramente formal, ou seja, procura insólita pela significação e sentido perdidos. Assim, enquanto patrimônico mnemónico das práticas de representação brasileiras seiscento-setecentistas cumpre o esforço de investigação sistemática e constante dos processos de produção e recepção das alegorias visando seu entendimento enquanto repositórios das premissas sociais vigentes no período de dominação portuguesa, clarificando e desvelando um texto oculto, muitas vezes, aos seus contemporâneos e praticamente hermético na atualidade. 


\section{REFERÊNCIAS BIBLIOGRÁFICAS}

BENJAMIN, Walter. Origem do drama barroco alemão. Tradução: Sérgio Paulo Rouanet. São Paulo: Brasiliense, 1984.

BRUZZI, Hygina Moreira. O ornamento estruturante: Reflexões sobre a primeira arquitetura barroca de Minas Gerais. Belo Horizonte: ACR - EAUFMG, 1999.

BUXÓ, José Pascual. El resplandor intelectual de las imágenes: jeroglífica y emblemática. In: Juegos de ingenio y agudeza: la pintura emblemática de la nueva Espanã. Barcelona: Museo Nacional de Arte, 1994.

CASTIGLIONE. O Cortesão. São Paulo: Martins Fontes, 1997.

CURTO, Diogo Ramada. O discurso político em Portugal (1600-1650). Lisboa: Centro de Estudos de História e Cultura Portuguesa, 1988.

GADAMER, Hans-Georg. Verdade e método. 3. ed. Petrópolis: Vozes, 1999.

GINZBURG, Carlo. Mitos, emblemas, sinais. São Paulo: Companhia das Letras, 1991.

GRACIÁN, Baltasar. Agudeza y arte de ingenio. Madrid: Escapa-Calpe, 1974.

HANSEN, João Adolfo. Alegoria. Construção e interpretação da metáfora. São Paulo: Atual, 1987.

HANSEN, João Adolfo. Notas sobre o barroco. In: Revista do IFAC, p.11-12.

HANSEN. A sátira e o engenho: Gregório de Matos e a Bahia do século XVIII. São Paulo: Companhia das Letras, 1989.

HANSEN. Alegoria - Construção e interpretação da metáfora. 2. ed. São Paulo: Atual, 1987.

KANTOROWICZ, Ernest H. Os dois corpos do rei - um estudo sobre teologia política medieval. São Paulo: Companhia das Letras, 1998.

KOTHE, Flávio R. A alegoria. São Paulo: Ática, 1986.

LIMA, Luiz Costa. O controle do imaginário - Razão e imaginação nos tempos modernos. Rio de Janeiro: Forense universitária, 1989.

MÂLE, Emile. El arte religioso del siglo XII al siglo XVIII. Cidade do México: Fondo de Cultura Económica, [s.d].

MARAVALL, José Antônio. A cultura do barroco - análise de uma estrutura histórica. Barcelona: Arial, 1990.

MENESES, Sebastião Cesar de. Summa politica offerecida ao Principe D. Theodosio de Portugal. Amsterdam: Simão Dias Soeiro Lusitano, 1650.

PLATÃO. República. Tradução: Pietro Nassetti. São Paulo: Martin Claret, 2004. 
QUINTILIANO. Instituições oratórias. São Paulo: Cultura, 1994.

RIPA, Cesare. Iconologia. Milano: Editori Associati S. p. A., 1992.

SARDUY, Severo. Barroco. Lisboa: Veja, 1989.

SEBASTIAN, Santiago. El baroco iberoamericano - mensaje iconográfico. Madrid: Encuentro, 1990.

SUAREZ, Francisco. Defensio Fidei III, principatus politicus o la soberania popular. Madrid: Consejo superior de investigaciones cientificas, 1965.

TESAURO. Argúcias humanas Argúcias humanas. In: Il Cannocchiale aristotélico. Tradução: Gabrielle Cipollini e João Adolfo Hansen. In: Revista do IFAC. Ouro Preto, no 4, IFAC/UFOP, p. 310, dez., 97. 